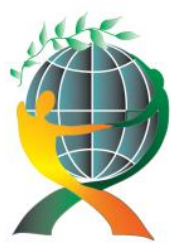

\author{
(online) $=$ ISSN $2285-3642$ \\ ISSN-L = 2285- 3642 \\ Journal of Economic Development, Environment and People \\ Volume 4, Issue 2, 2015
}

URL: $\underline{\text { http://jedep.spiruharet.ro }}$

e-mail: office jedep@spiruharet.ro

\title{
Which Governments May Control the Mass Media: Iran and Kurdistan as a Case Study?
}

\begin{abstract}
Araz Ramazan Ahmad ${ }^{1}$
${ }^{1}$ University of Raparin

Abstract. This paper is the comparative study in order to discover the motives of using censorship on Media. The main argument of this study is to determine the "Using of Censorship on Media in different government states" Consistently, the study depends on document analysis method and academic sources as well. Correspondingly, the study focuses on Media and democracy and then Mass Media in Iran and Kurdistan region of Iraq. Finally, the law of press in Iran and Kurdistan will be analysis to know the key elements of censorship in both governments.
\end{abstract}

Keywords: Iran - Iraqi Kurdistan - Media - Censorship - democracy

JEL Codes: L82, D83

\section{Introduction}

Commonly, controlling mass media is a serious threat that faces democracy in the world; some governments practice some procedures to control the mass media, when media appeared that was happened and it have been continuing especially in the Middle East. Likewise, Media is an important issue in modern and democratic countries hence the human beings should work for freedom of expression as the human did several wars in order to speak out freely and exchange information, so how they would accept silence in twenty first century. Similarly, Nordenstreng (2001) argues that human beings cannot leave the journalism out of this neutralization, the media specifically TV has a great relation with democracy since it is a powerful democratizing power, however, the mass media could be a part to destroy public space of discourse they open up to grow the community and freedom of expression. In other words, it is the start to decrease morality among mass media and audiences thus controlling is one of the pressures completely threatening the freedom of media. Besides, DAY (2001) believes that restricting media occurs while a specific government or individual enforces its political values on others by limiting expressions. In addition, Siebert, Peterson and Schramm (2000) claims that there are Four Theories of the Press in the world; the "Authoritarian theory" in which media works for the benefits of the government, and advance the policies of the government in power and ownership can be either private or public. The second theory is "Libertarian". This theory takes the philosophical ideas that human being is a rational well-being and can

${ }^{1}$ Corresponding author. Tel.: +9647701573122

E-mail address: araz.ahmad85@raparinuni.org, araz.ahmad@aol.co.uk 


\author{
(online) $=$ ISSN $2285-3642$ \\ ISSN-L = 2285-3642 \\ Journal of Economic Development, Environment and People \\ Volume 4, Issue 2, 2015 \\ URL: $\underline{\text { http://jedep.spiruharet.ro }}$ \\ e-mail: office jedep@spiruharet.ro
}

differentiate between truths and false. Hence, he can make a good choice among his choices either good or bad. While the third theory is "Social Responsibility" that is an outgrowth of the libertarian theory. However, social responsibility goes beyond "objective" reporting to "interpretive" reporting. Lastly, the "Soviet-Totalitarian" or "Communism" theory aims to contribute to the success and continuance of the Soviet socialist system, and especially to the dictatorship of the party because the Ownership was public. But journalists are most interested in the libertarian theory and the social responsibility theory as a background for today's free press. Additionally, democracy is an essential condition for free media or modern media. In states where the political systems are non-democratic, such as in Islamic Republic of Iran, media is not free and it doesn't work as a modern media. In this essay threat of controlling on media will be discussed in non-democratic systems for instance in Iran and it will also compare and contrast the freedom of mass media between Iran and Kurdistan Region (KRG) in Northern Iraq.

\title{
2. Media and Democracy
}

Some experts believe that media and democracy have great relations and they leave enormous effect on humanity to establish a modern and a new system for their lives. According to Cambridge dictionary (2011) it's potential that democracy is the norm in liberty and equality among beings, or a structure of administration created on this acceptance, in which power is whichever held by chosen senators or openly by the individuals themselves. Moreover, Jefferson (1991) states that "If it were left on me to decide whether we should have a government without newspapers or newspapers without government, I should not hesitate a moment to prefer the latter." It has explained that media is crucial in democratic systems because if the media doesn't distribute critical information about unwanted affairs, democracy doesn't flourish. In a similar way, Dennis and Snyder (1998) maintain that modern media means a media that backs up the democratic order of liberate votes, common law, politically aware independence, common rights, characteristic government and an independent judicial system.

Democracy and media live together side by side by supporting each other through a process of cooperation about common affairs would be fruitful. Currently media is an important democratic art in human life since only mass media can deliver the public knowledge and it is essential for the democratic progress, whereas, it's not easy to work on cases about free media in non - democratic systems because it requires explaining how media work in totalitarian countries in which some politicians monopolize everything. Moreover, Vali (2004) argues that some of non-democratic governments always try to control media because they believe that media is the biggest hazard opposing their power. For example, Islamic Republic of Iran is one of the totalitarian governments that have controlled media since 1979, and that an Islamic group obtained power in the country. However, some democratic governments consider that media is one of the significant elements for any democratic country such as Kurdistan Region in northern Iraq. It has a modern law of journalism since 2007-2008, although it is a new region in the world without its independent territory. 


\author{
(online) $=$ ISSN $2285-3642$ \\ ISSN-L = 2285 - 3642 \\ Journal of Economic Development, Environment and People \\ Volume 4, Issue 2, 2015 \\ URL: http://jedep.spiruharet.ro \\ e-mail: office jedep@spiruharet.ro
}

\title{
3. Mass Media in Iran and Kurdistan
}

Both Islamic Republic of Iran and Kurdistan have press laws although they have a different law and culture for media and governmental systems. According to BBC (2011), it is probable that Iran became a sole Islamic Republic in 1979 when the kingdom was defeated and religious extreme individuals controlled power under "Ayatollah Khomeini." The Iranian government has a good justification to control mass media through the country and apply censor on online journalism, because the system allowed implementing technical restrictions on mass media by limiting and implementing harsh polices, that is why Censorship make bigger to political and human rights web Pages. Furthermore, a lot of Social media sites have been closed in Iran such as: "Face book, Twitter, MySpace, Flicker and YouTube." Similarly, consistent with Press Law of Iran (1986) is ratified in 1986, and its decision-making By-law in1987, the law started "Let us swear by the pen and whatever is written." it taken from "Holy Quran", whereas, the state use censor on media and freedom of expression. Besides, according to BBC (2007), Shirin Ebadi, an Iranian Nobel peace laureate, supposed that Iran is getting worse in using censorship and the country doesn't like its local affairs and actions inside the state to be reproduced in the outside world. Also, Ebadi believed the regime of Iran tries to restrict the spread of information about current issues in the world. In addition, Iranian Online journalism has encountered a big hazard by political system in the country, since the system does not accept working social networks through the state; it also applied the control on mobile phones and every kind of online media. Additionally, Sreberny and Gholam (2010) claim that newly Iranian government intend the creation of sites booming news, editorials and blogs contain a new ethical not accessible within the command - controlled networks, for example, the telecommunication ministry of Iran in 2004 declared that it would begin filtering out 'immoral' movies and voice messages directed by mobile phones. Moreover, restriction and control operate several persons, excluding editors, authors, correspondents and normal people who follow the net to gain information to create discussion for free communication. On the other hand, the government doesn't care for freedom of mass media and the role of democracy. Besides these behaviors against media, the state keeps blocking sites. For instance, 2008 was a harsh year for media freedom in Iran, within the country creation noise about additional extending mass media, traditional controls and with the figures of bloggers and reporters in prison increasing. Furthermore, Sreberny and Gholam (2010) consider that Since 2000 the government has completed list of websites and blogs to be controlled, and 15,000 websites had already been drawn up by the government in 2003 and directed to the internet service providers to be blocked, in the same time, the government arrested some people in April 2009 like "Omid Reza" who was the first Iranian blogger to die in prison because he used online media to gain information. Additionally, According to Aljazeera (2009) the Iranian powers are killing not for only a traditional figures conflict - says their sideways of the story through country round news establishment and brawling with the story on global mass media vents. Conversely, the situation of media is very different in Kurdistan Region because the governmental system in Kurdistan is non-Islamic system it's the main factory of dissimilarity between these two systems. In the same way, Berzinjy (2001) claims that nowadays human beings live in contemporary world and it doesn't have any justification to using censorship on mass media by governments, whereas many governments use censor on media since sometimes they face some security challenges. For example, Kurdistan Regional Government in some situations used censor on media because the location of Kurdistan is very hazardous as it is located in the mid of three states, Iran, Turkey and Syria. It has also a historical political conflict with these countries, thus 


\author{
(online) $=$ ISSN $2285-3642$ \\ ISSN-L = 2285-3642 \\ Journal of Economic Development, Environment and People \\ Volume 4, Issue 2, 2015 \\ URL: $\underline{\text { http://jedep.spiruharet.ro }}$ \\ e-mail: office jedep@spiruharet.ro
}

it is not easy to publish information particularly against them. As a result, the above examples explained that censorship exists everywhere.

Differences between Iran and Kurdistan are about significant democratic political cultures or modern media values. Moreover, Salih (2005) believes that Middle East is a risky place for reporters to work; Iran is the fourth state for controlling mass media in the region, and 27 correspondents were arrested in the Middle East in 2004 for ejaculation; libel the president of the country, affront Islam and publishing untrue information, half of them in Iran.

\title{
4. The Law of Press in Iran and Kurdistan
}

If we want to obtain a correct comparison between Iran and Kurdistan, the press laws in both countries should be taken into account. Iran's Press Law was ratified on 19 March 1986 and it's passed on 31 January 1987. In the introduction of the Press Law in Iran it is simplified that mass media has freedom of expression but the information that will be published does not infringe Islamic values or the public code, as it is stated in article 24 of the constitution. On the contrary, 2008 was the golden year for Kurdish journalists in Kurdistan because for the first time in that year the Kurdistan Regional government passed on the press law; now Kurdistan has the most liberal mass media autonomy. The essential law of Journalism in Kurdistan defends the reporters to keep save their sources, stops the imprisoning and illegal accusations of journalists.

According to Iranian law of press the journalists can work against colonist political for example In Chapter two, Article two explained that journalists should work against the face of colonial principles which intends to abuse Islamic ideology. It should encourage honest Islamic principles. And if they did not do it the government can charge them so it's a proper way for controlling the mass media, however, in "essential law of Journalism in Kurdistan" does not have any words about this issue and if the journalists libel any nations the law charges them because the human beings should respect each other in the world.

The Iranian law of press is very complex because in some parts it mentioned that freedom of expression is fundamental for journalists but it always revisit for Islamic values, such as in chapter three, article three illustrated that mass media has a right to spread criticisms, opinions and ideas from persons and official sources for society, but information should accordingly promoting and encouraging respect for the Islamic traditions and the greatest attention of the public. Nevertheless, the first chapter - article two in "essential law of journalism in Kurdistan" explained that mass media is free and there is no restrictions also freedom of expression for every type of press, secured to all civilian in regarding to the rights and liberties of persons and their private lives. Likewise, in the second and third points in this article the journalists have right to gain important evidence and information for people from different sources according to the law, the journalists also have right to save the sources of stories gained from confidential points, and in the fifth point clarified that the newspapers never forbidden and the authority cannot control them.

The chapter four of Iranian law of press is the biggest threat in front of democracy and modern mass media because it explained that mass media and prints are allowed to spread news bulletin just excluding it while it violates Islamic values and codes as it is defined in this chapter, for example print disbelieving articles or subjects which abuse the Islamic values and encourages issues which could disrupt the basis of 


\author{
(online) $=$ ISSN $2285-3642$ \\ ISSN-L = $2285-3642$ \\ Journal of Economic Development, Environment and People \\ Volume 4, Issue 2, 2015 \\ URL: http://jedep.spiruharet.ro \\ e-mail: office jedep@spiruharet.ro
}

Islamic Republic. In addition to spread indecent and actions which are banned by religion and printing obscene photos, topics which disrupt society decency or publishing luxury and well-being, or support people within or outside the country to act against the Islamic Republic of Iran and national interests. While spreading confidential information and evidences about the armed militaries, military plans, discussion and closed debates of the Islamic Consultative Assembly without legal permission. Moreover, belittling the Islamic leaders in hieratical levels would offend the authority. Besides, offending people who have reputation in state positions by libels, photos, and cartoons is not allowed. Regulating the commitment of plagiarism and quoting illegally from media outlets which are offending Islamic principles and laws on national and international arena would be restricted by Islamic executive law.

The fighting is a sense of human instincts that's why they apply law to reduce war against each other, but some laws indirectly has a big justifications and supports to break peace among individuals. However, some rules are help humanity to live peacefully for instant in chapter three - article six in "essential law of journalism in Kurdistan" confirmed whether the newspaper spread incorrect data to the individuals, they have rights to claim legally to answer the broadcast or news, and the editor in chief should publish respond in the same page by the same magnitude, and if the newspaper did not publish the answer or correction the newspaper face fine that amount is not unless one million diner and not more than 2 million diners as punishment, and sometimes the editor can refuse the respond for example if the newspaper has an evidence that their information is correct, and when the answer send after 90 days or the answer has conflict with the law. Similarly, according to Rudaw (2011) the Labor MP Meg Munn, who served as Minister for Women and Equality from 2005 to 2007 in the UK, said: "We want to support a Kurdistan that is respecting Human rights and freedom of expression; however, we understand that democracy in Kurdistan is not complete yet."

Some governments are working to limit the freedom of mass media by limiting and issuing a license of the applicant for example in chapter five in Iranian press of law shows the qualifications of the Applicant and Stages of Issuing a License such as Article nine illustrate that a real person who applies for a license must have the following qualifications: Be free of moral corruption, or a record of criminal conviction which, also according to the Islamic code, strips him/her of social rights; and almost all the officials in Iran such as in government, parliament, council, companies and banks those who have publicly spoken in favor of the former regime through the news media, radio or TV, are prohibited from publishing a publication. Correspondingly, According to Al Jazeera (2010) its certain that "the Iranian authorities have prohibited a reformist daily newspaper and a moderate weekly magazine run by the family of Mehdi Karroubi, an opposition leader." additionally, Referring to Article tenth the Press Supervisory Board shall consist of devoted Muslims who possess the required scientific and moral competence and are committed to the Islamic Revolution as follows: Entry to and exit from the country of publications shall be in accordance with the basis of religious codes and the constitutional Law of the Islamic Republic as mentioned in Article 22. The regulations covering entry and exit of publications to and from the country shall be formulated within six months via the Ministry of Islamic Culture and Guidance and while being ratified by the Islamic Consultative Assembly, additionally the Article 27 clarify that the Islamic republic will revoke the license of those whose writings' insult the Leader or Council of Leadership of the Islamic Republic of Iran or senior religious authorities (top Islamic jurisprudents), not just the license of the publication but others who are involved as manager and editors will be subjected to punishments which are stated in constitution. On the 


\author{
(online) $=$ ISSN $2285-3642$ \\ ISSN-L = $2285-3642$ \\ Journal of Economic Development, Environment and People \\ Volume 4, Issue 2, 2015 \\ URL: http://jedep.spiruharet.ro \\ e-mail: office jedep@spiruharet.ro
}

other hand, according to the "essential law of journalism in Kurdistan" everyone has right to obtain a License of publication by government. In contrast, chapter 6 in Iranian law of press is about violations and according to Article 24 in this chapter, if any one tries to publish confidential military documents and orders, and secrets of the Islamic Revolutionary Guards Corps (IRGC), or, maps of military installations and fortifications during war or peace time in the press, will be treated according to law and the court decided on his punishments, and what mentioned in Article 25 is the importance of pushing people through the press, expressly, overtly instigates and encourages people for committing crimes against the domestic security or foreign policies of the state, as specified in the public penal code, if he/she accused of committing a crime while evidence be available then his/her action bear adverse consequences. However, if no evidence is found on such consequences then he/she would face a religious decision according to Islamic penal code. Also In Article 26 clarified that whoever intends to insult Islam and its principles via the press and his/her guilt amounts to apostasy, ought to be punished as leftist who violate religious principles according to the Islamic penal code. But Consistent with chapter fourth/ article seven in essential law of journalism in KRG journalists are freelance and they have no power in the presentation of their work additional that the legislation, and the information spread by journalists should not act to public disturbance, and the journalists can save their sources, excluding by legal decision, they also have a right to attend for public conferences. This chapter illustrated if any person affront or offensive journalists, are penalized by law, and in chapter five / article eight explained impunity for journalists in Kurdistan, in the first point police can't investigate with journalists and they can't search their houses unless the court authorizes to do.

The Islamic republic of Iran banned journalists when they published information against Iranian law, likewise, According to Article 28, any media outlets that offend and abuse the social decency is strictly forbidden and would be punished by Islamic law, while sticking to publish such kind of publications would case the revoke of the publication's license and facing severe punishments. Similarly, article 31 concentrated on violating and threatening personal confidential affairs, is prohibited and the manager in charge will be punished according to law. However, in Kurdistan is different because when the journalists face problems and when they do not win the case, the law charge them by an amount of money according to law as penalty, for example article nine illustrated some points about fined journalists and editor in chief by an amount that is not fewer than one million diners and no extra than five million diners when they printed those points: when they abetment societies to grouch or disrelish odds and dissonance among the elements of community, despised the religious principles, sacred and spiritual, Any information relevant to the private life of people until if correct, because it leave impact on their personality or publish swearing and aspersion, if the newspaper repeat the action, the law could raise the fine amount to twice. Besides, article ten shows that conditions of article nine do not apply for the colleges and scientific research centers or scientific purposes.

\title{
5. Conclusion
}

In this essay a brief introduction about media and four theories of the Press in the world; have been explained, and controlling mass media in different governments like Islamic Republic of Iran and the freedom of expression in Kurdistan are argued, also the Media and democracy have been clarified. Besides, Media in Iran and Kurdistan have been illustrated, and then the comparison between Press law in Iran and Kurdistan and both governments systems have been discussed. Finally, it can be seen that controlling 


\author{
(online) $=$ ISSN $2285-3642$ \\ ISSN-L = $2285-3642$ \\ Journal of Economic Development, Environment and People \\ Volume 4, Issue 2, 2015 \\ URL: $\underline{\text { http://jedep.spiruharet.ro }}$ \\ e-mail: office jedep@spiruharet.ro
}

media always exists in the twenty first century in some countries in the world particularly in the Middle East such as in Islamic Republic of Iran, and it has shown that Kurdistan is a new region in the world however it has a modern law for press that its better than Iranian law of press. As well as, it is revealed that "Social Responsibility" theory is the best system for press rather than "Authoritarian", "Libertarian" and "Communism" theories, because it has more freedom for mass media and it can be adapted with democracy. In my opinion, controlling media is the biggest intimidation in front of democracy and modern media.

\title{
6. References
}

[1] NORDENSTRENF, Kaarle (2001). Media and Democracy. Journal of Television \& new media, 2 (1), 57.

[2] DAY, Nancy (2001).Censorship or Freedom of Expression. USA. Lerner

[3] JEFFERSON, Thomas (1990). Toward a Theory of Press-State Relations in the United States. Journal of Communication, 40 (2), $103-127.4$.

[4] DENNIS, Everette and SNYDER, Robert (1998). Media and democracy. USA, Library of congress.

[5] VALI, Nasr (2004). Iran's Democracy Debate. Journal of Middle East Policy, 11(2), 94.

[6] BBC (2011). Iran profile (Online). Last Updated 9 November 2011 at: http://www.bbc.co.uk/news/world-middleeast-14541327 7.

[7] BBC (2007). Iran censorship 'getting worse' (Online). Last Updated 14 June 2007 at: http://news.bbc.co.uk/1/hi/world/middle east/6751819.stm

[8] SREBERNY, Annabelle and KHIABANY, Gholam (2010). Blogistan: The Internet and Politics in Iran. London. I.B. TAURIS.

[9] BERZINJY, Dana (2011). Freedom of Speech in Kurdistan Regional Government (KRG) /Iraqi Kurdistan (Online). Last accessed 9 August 2011 at: http://www.ekurd.net/mismas/articles/misc2011/8/state5327.htm

[10] Al Jazeera (2009). Media control in Iran (Online), Last updated 26 Jun 2009 at: http://www.aljazeera.com/programmes/listeningpost/2009/06/200962612250139720.html

[11] SALIH, Roshan (2005). Report lists worst censorship culprits (Online). Last Accessed 4 May 2005 at: http://english.aljazeera.net/archive/2005/05/20084101472133608.html

[12] SIEBERT, F, PETERSON.T and SCHRAMM, W (2000). FOUR THEORIES OF THE PRESS. Stratford, Ayer.

[13] KURDISTAN (2008). The Essential Law of Journalism in Kurdistan, Erbil, Regional Presidency.

[14] IRAN (1987). Press Law. Tehran. Regulation of the Media in the Islamic Republic of Iran.

[15] RUDAW (2011). British MP: We Want to Support a Kurdistan that Respects Human Rights (Online). Last accessed 26 JUNE 2011 at: http://www.rudaw.net/english/kurds/3781.html

[16] CAMBRIDGE Dictionary (2011). Definition of Democracy (Online). Last accessed 28 December 2011at: http://dictionary.cambridge.org/dictionary/british/democracy?q=democracy 